\title{
CREMATION VERSUS BURIAL.
}

By W. HOLDER, M.R.C.S.

I

WOULD desire to say that we, as sanitarians, are responsible, as each one individually is, for our own part. Let me read an extract from some writings of Dean Church. It runs thus :-

"We are like soldiers in a widely extended battle-field, of which we know not the phases, of which we seem utterly powerless to control its issues; but we are responsible for our own part. Whatever goes on elsewhere, let us not fail in that. The changes in the world, which men think they are bringing about, are in the hands of God; with Him, when we have done our duty, let us leave them."

The object of this Congress is to unravel some of the sanitary difficulties of the problem of the widely extended battle-field of discase, of which the most expert know not all the phases. The microscope has shown the minute form of some germs of disease, yet their genesis, their life history and power for evil under unknown phases, are, up to now, not a demonstrated proof. Yet we know enough to see that the buried germ is not a dead danger; that through worm, mosquito, fly, wind, or rain wash, it may, years after interment, awake to spread its malignant disease. What, then, is our cluty, if not that we shall act the part for which, with knowledge in our possession, we are responsible? If we recognise this, then the members of this Sanitary Congress will support Cremation at every opportunity.

The steady progress of sanitary precautions has materially lengthened the prospect of life, and lightened the costs of the life-risks of insurance companies. The substitution of Cremation for burial will continue the struggle for health against disease, helping our workers and increasing their chances of happiness. The working men of Hull have the credit of being the first of their class to show England that they recognise the advantages of Cremation, not only have they at the meeting of delegates unanimously approved of this, but one of the members of a friendly society, a dock labourer, requested his club members to see his body was cremated. At his death his desire was obeyed. 
Cremation is now beyond its experimental stage. Whether you approve of its principles or not, you and I are under the deepest obligation to it. For instance:-during last year several cases of plague came in a ship to the port of Hull. In this plague attack all but one died. In plague cases, from health to death is but a question of a few hours. The tissues of the victims were saturated, in lungs, blood-ressels, and glands, with the infective germs of the disease. If the remains of these plague infected bodies had not been quickly cremated it is not unlikely the disease might have broken out in Hull, and from thence be sent to Bradford and other inland towns; hundreds of lives might have been sacrificed, and the trade, of the cities infected, permanently injured. It is nothing but fair to credit Cremation with the important fact that within an hour or so, the diseased tissues of these unfortunate men were deprived of all their malignant infection, were innocuous, pure, white, calcined remains which could have been handled with impunity. Who can say that a plague with its sequences of devastation and expenditure was not thus stayed? Such is a national as well as local evidence of the value of Cremation to humanity.

The objection to Cremation can only come from those who will not think out the horrors of burial of bodies.

For sentiment's sake compare Cremation with earth decay by burial. In Cremation, within an hour the vapours and gases have evaporated into the air, and the whole solids of the body are left as clean, pure, sanitary ashes. Compare this with the sloughy putridity, full of infective germs, of a buried body after one, and sometimes after seven and eight years of burial and then ask what can be your verdict of the two systems? It must be, if you reason at all, that one follows the laws of science and wisdom, whilst the other is unworthy of-nay, it is not generally followed bysavage nations.

Cremation is more to the benefit of workers than that of any other class. Their health is their strength-Their strength their wealth-Their wealth is, or should be, their comfort. No man should be poor who is strong. The success and future happiness of those around men depends on their health. The savings of a vigorous healthy life should bring comfort and support to old age and declining years. Vigorous healthy surroundings then are their necessity. How will burial prevent this blessing? How will cremation make it possible? This is not difficult to explain. You have all here an intimate knowledge of "Disease Germs." It is easy to show microscopically the different forms of spores, bacilli, and bacteria of specific disease infective germs-a body dead of typhoid has the bowels swarming with these germs. It is now recognized that not only the 
germ, but also their exuded toxic poisons carry diseases. The drainage from Cholera graves has sereral times re-awakened Cholera. Yellow Fever and Anthrax lave been propagated from the soil in which bodies dead of these disenses were buried. Here we have evidence that earth burial tends to deprave health. Ought we not to see if there is not a better method to prevent it? The refining influences of heat have removed for all ages dross from the precious metal, and so it can from cliseased tissues. Cremation clarifies and refines the diseased dead, kills the germ threatening health, and thus lessens the dangers from diseases with their attendants weakness and poverty.

If we can, then, by discontent with burial, which is crude, umclean, and disease-giving, end it, and by discontent bring Cremation, with its purity, perfect cleanliness and reason, we shill displace that which makes for disease and restore that which tends to the uplifting of health with its attendant blessings to mankind. This is a task wortly even of this important Congress.

Another attendant danger on burial is the gruesome graveyard with its straight-edged tablet. In its prime it is a resort of woe, in its age often an oasis of neglect. In Hull, dockers have been rendered sick and ill when working 100 yards from a graveyard. The dry heat of summer cracked the earth, and the gases poisoned the air.

One of the benefits of Cremation is that it will effect great siving of land waste, especially in towns.

Having shown these benefits from Cremation, I have the right to say that by the Cremation Act of 1902, the Legislature has done nothing to encourage but to retard its progress. I claim the sympathy of this Congress to this complaint.

\section{Hindrance offered To Cremation by Unequal Laws.}

It is not so much that the Cremation Act of 1902 is unnecessarily searching and severe as it is that the disparity under which Cremationists are placed compared with those who practice the unsanitary method of earth burial is so unjustly enlarged by this enactment.

It is an astounding statement, but not less a true one, that to bury a dead body no legal regulations exist, but on the contrary to cremate a dead body legal requirements, unnecessarily expensive, have been, by this Act, imposed. This is a disparity and a wrong which this Congress, in the interests of public health, is urgently invited to put right.

It will have given most of you, who have heard so much lately of the 
legal argument against. Cremation, a shock to learn that not one legal formality is required to procure the buvial of a dead body; this surprise is great, when you recall the numerous murders which have been hid by eartl burial, a recent instance of which is to be found in the Chapman (Poluski) case.

"The law even permits burial previous to registration of death."

These astounding words are not mine, they are an extract from a Blue Book report, summarising the evidence obtained by a Government Department, appointed to bring up Regulations under the Cremation Act, 1902. It is in evidence that it is not even a legal necessity at a burial to produce so much as a burial certificate; in fact, no documents are necessary for the burial of a body. When one is produced it is lirected to be given to the officiating person performing the burial service; this officiating person need not be a clergyman. Whoever he may be, he may crumple it up in his pocket, or put it in the fire, as he pleases, for he has no directions to file or enter it in any permanent record. Certainly no document need be given to the superintendent of the cemetery, unless a local bye-law requests it. You would think this defect needed legal correction, but no, it is left mamended, but on the unoffending heads of Cremationists has fallen stricter and oppressive officious legal regulations, regulations wasting money and time. If the regulations under the Cremation Act are so necessary to prevent poisoning, and here it must be remembered that not the slightest suspicion up to this has yet rested against a cremated case, surely the least that can be done by the State authority is, that it should level up to an equal standard of severity the legal regulations for burials in earth. It is this amendment of the law which I venture to ask this powerful Congress, by resolution, to urge on the Home Office and the Government.

To show how reasonable this is I will quote further from the Blue Book already mentioned: on page six you will find the following paragraph :-

"In some cases we found that the bodies of murdered persons were buried"-please note, not cremated — "without any certificate of the cause of death. The law unfortunately permits burial without certification of the cause of death."

The scope of inquiry of the Government Departmental Committee, from which I quote, was, of course, limited to its directions, viz., to inquire into Rules and Regulations for Cremations: but those reading the evidence and the report on the evidence will see that from beginning to end it is, iter se, a justification for Cremation and a condemnation of 
burials. It proves the legal dangers of earth burial, and the safety of the then existing Cremation Regulations up to the hilt. I had the duty of giving evidence before that Commission. I ventured there to point out that in all the poisoning cases, even that of Chapman (Poluski), then under trial, no murderer had been brought to trial until suspicion was aroused about his last, generally unburied victim ; that is to say, none of the early victims had any consideration, nor would they have had any, if it had not been that the last case had come under suspicion. It is only when you find out the immense number that different murderers have put away, without suspicion, that you begin to see the clangers of earth hiding. It is left to the imagination to gauge, if these murderers could put so many into the earth without being detected, how many other victims of other murderers must be undetected, and their murderers unpunished.

Another astonishing fact disclosed by the Blne Book, is that, even the first of these murders would have been discovered, if the attempt had been made to cremate them under the old regulations of Cremation.

This is all fully confirmed by the Blue Book report. It says:-

"In some such cases (as in Palmer's) the facts of the earlier murders did not come before the jury at all."

Then, after some words concerning exhumations, which it says merely strengthens the evidence, the report goes on as follows:-

"But against this advantage must be set the by far more important consideration, that an effective method of death certification, by bringing to light some of the earlier crimes, at the time they were committed, would prevent altogether the commission of the later crimes."

Surely this is a pungent reason why the regulations for burial of the dead should be brought up to the level of those demanded for Cremations. Let us see then what is said about the efficacy of the regulations for cremations, as they were before Parliament made them more stringent in 1902.

The report says :-

"Mr. F. W. Lowndes, the Liverpool Police Surgeon, who was intimately acquainted with circumstances of the case of Higgins and Flannagan, two women who poisoned eleven persons for the sake of insurance money, in his evidence before the Death Certification Committee, expressed strongly the opinion that the enquiry required by the Cremation Society 'would have undoubtedly revealed the fact that the deaths (of the earlier victims) were not natural,' and would have saved the lives of their earlier victims; and a 
similar remark would apply to the case of Mary Ann Cotton, already alluded to, whose victims numbered no less than twenty."

This should be all sufficient to show this Congress that it was not the rules for Cremation, but those for burial that needed strengthening. Here, in two cases, is an admission that, at least, thirty lives would have been saved from the poisoners, if the burial certificates for the first victims had been as stringent as those required for Cremation; yet, in spite of this, in a topsy-Gilbertian-turvey-Sullivan-way, the State Rulers make more stringent that which was strong enough, and do nothing to amend that which they themselves have shown is a danger and enemy to life. I would ask, therefore, the help of this Congress to put this wrong right, by passing the following or some similar resolution :-

1st. "That this Sanitary Congress regrets that the report of the Departmental Committee, appointed to prepare a draft of the regulations under the Cremation Act, 1902, was not authorised to recommend some legal regulations to govern the burial of the dead. Whilst this Congress welcomes any death certification which ensures security for life, it feels the revelations made in the above report of the insecurity for life shown by the want of regulations for burials, and the security for life afforded under the old regulations for Cremation, makes it manifest that immediate legislation is needed to level up the regulations for burials-under which the crimes detected and undetected have been committed-to no less a stringency than those enforced for Cremation, and recommends the Council to pray the Home Office and the Government to take steps to secure this needed reform."

2nd. "That such resolution be forwarded to the Premier, the Home Secretary, and Sir Walter Foster."

These resolutions were not put to the meeting. 